\title{
Study on Innovation Behavior of State-owned Pharmaceutical Enterprises Based on the Viewpoint of Ownership Structure Reforming
}

\author{
Shengyi Shi ${ }^{1}$, Guangping Wang ${ }^{2}$, Yanfei Huo ${ }^{3}$, Baxian $\mathrm{Yi}^{3} \&$ Xiaoming $\mathrm{Wu}^{1}$ \\ ${ }^{1}$ China Pharmaceutical University, Nanjing, China \\ ${ }^{2}$ Shanghai Institute for Food and Drug Safety, Shanghai, China \\ ${ }^{3}$ China State Institute of Pharmaceutical Industry, Shanghai, China \\ Correspondence: Xiaoming Wu, China Pharmaceutical University, Nanjing 210009, China. E-mail: \\ xmwu@cpu.edu.cn
}

Received: July 13, 2016 Accepted: July 29, 2016 Online Published: October 30, 2016

doi:10.5539/jpl.v9n9p195 URL: http://dx.doi.org/10.5539/jpl.v9n9p195

\begin{abstract}
It is necessary to play a leading and exemplary role in the implementation of Chinese innovative development strategy, because of the economic, social and political status of state-owned pharmaceutical enterprises. Based on describing pharmaceutical ownership reforming and innovation status, the paper analyzed the dynamic innovation performance of the State-owned pharmaceutical enterprises by the Malmquist index of DEA (Data Envelopment Analysis), and result shows that the biological product field of state-owned enterprises obtained better innovation performance. Then the paper discussed the innovation performance of state-owned pharmaceutical enterprises by the empirical analysis of Panel data model, the results showed that the state-owned enterprise have the serious status of $R \& D$ resource concentrating and excessing, but it is still achieve major force of Chinese pharmaceutical economic growth based on innovative activities. At last, the paper offered the upgrading road of state-owned enterprises innovation capability, such as the market radiating and integrating, micro-cooperation, organizational restructuring, and cross-regional integration.
\end{abstract}

Keywords: ownership structure, state-owned, pharmaceutical enterprise, innovation

\section{Introduction}

In the third plenary session of $18^{\text {th }}$ Communist Party of China (CPC) congress clearly put forward to the reform of the state-owned enterprise operation and management mode, get rid of the monopoly of the past, manage assets mainly to regulatory capital mainly to strengthen the state-owned capital supervision; especially state-owned enterprises take the mixed ownership reform mode, will stimulate the capital vitality of China, driven by the investment operation of social capital in a broader field which the industry gradually break the monopoly. "Vigorously promote the reform of state-owned enterprises" has become an important part of the supply side structural reform in the 2016 national government work report. In September 2015 the central government issued "on the promotion of state-owned cultural enterprises in putting social benefits first, to achieve social and economic benefits of the unity of guidance", the state-owned enterprises have the function to achieve the integration of economic responsibility, political responsibility and social responsibility. Therefore, analyzing the innovation behavior of state-owned enterprises under the background of the ownership structure reforming will give a better play to the positive role of the state-owned pharmaceutical enterprises in the implementation of national innovation and development strategy.

\section{Pharmaceutical Ownership Structure Reform Process and Innovation Activities}

\subsection{Institutional Evolution of the Pharmaceutical Ownership Structure}

Pharmaceutical enterprise ownership structure reform, put forward earliest in third Plenary Session of the 12th CPC Central Committee in 1985, proposed pharmaceutical state-owned industrial enterprises director responsibility system, and carry out "attracting external economic joint internal economic" mode to develop the lateral economic association. In 1987, a group of pharmaceutical enterprise groups were formed by the combination of lateral economy. Accordance with the principle of the separation of ownership and management, 
pharmaceutical companies gradually contract responsibility system. In November 1993, the CPC put forward the reform goal of "further transformation of the state-owned enterprise" in the third plenary session of the 14th CPC Central Committee. In January 1997, it focuses on the pharmaceutical accelerate economic restructuring in the Medicine Management of the National Conference of Directors. In the third plenary session of the 18th the CPC Central Committee, the CPC put forward to develop the mixed ownership economy, such as the state-owned capital, collective capital, non public capital and so on ". In August 2015, "the CPC Central Committee, State Council guidance on deepening the reform of state-owned enterprises" offer that "state-owned assets management system, the modern enterprise system, market-oriented operation mechanism, the state capital layout structure more reasonable"; In September 2015, the "State Council on the development of state-owned enterprises of mixed ownership economy views", and December "on the definition and classification of state-owned enterprises function guidance" and other policy documents, starting from the two dimensions of "classification" and" stratification", the reform of state-owned enterprises of mixed ownership space gives the specific implementation roadmap, to further promote the ownership reform of state owned enterprises.

\subsection{Government Innovation Policy and Medical Innovation Activities}

The 18th CPC Congress proposed "innovation-driven development strategy," the development of the pharmaceutical industry to rely on scientific and technological innovation, industrial structural optimization and upgrading elements, rather than the traditional energy resources drive. Since reform and opening up, the demand of traditional technology in China has been higher than that of innovative technology. Using traditional techniques it produced pharmaceutical products and the use of new technology to produce out of the same selling. The technological innovation motive power shortage is derived from the shortage economy under the mode of planned economy. As well as the new technical field needs a lot of capital and high technical personnel and to strictly implement the relevant quality system standards, leading producers tend to choose natural traditional techniques. Pharmaceutical industry "in 12th Five-Year Plan" development plan put forward "to establish and improve the enterprise as the main body of the technology innovation system, key backbone enterprise R\&D investment reached more than $5 \%$ of sales revenue, significantly improve innovative ability. Thus, the state-owned enterprises in the National Bio-pharmaceutical innovation technology support system in the construction of social responsibility and political responsibility of great significance.

Technological innovation is the engine of industrial optimization and upgrading and economic transformation, which as a strategic support to enhance the level and quality of the pharmaceutical industry. Organizational structure, core technologies and key generic technology research related business innovation support system, intellectual property protection and standardization of construction, innovation activity as structural adjustment performance boosters, thus contributing to economic restructuring and industrial upgrading pharmaceutical target. At present, the state-owned pharmaceutical enterprises shoulder the technological innovation and industrial structure adjustment goal and economic and political task. Enterprise innovation activities must be based on GMP, Pharmacopoeia and energy-saving emission reduction (ISO14000) as the prerequisite, in order to realize the technology of structural adjustment and industrial upgrading. "China Statistical Yearbook on High Technology Industry" shows that: in recent years, the state-owned chemical manufacturing technology innovation strength dropped significantly, while the intensity of technological innovation in the state-owned manufacturing industry has been growing slowly (Fig. 1 and Fig. 2). State-owned pharmaceutical enterprises in the direction of technological innovation and structural adjustment play a positive role in the market model. 


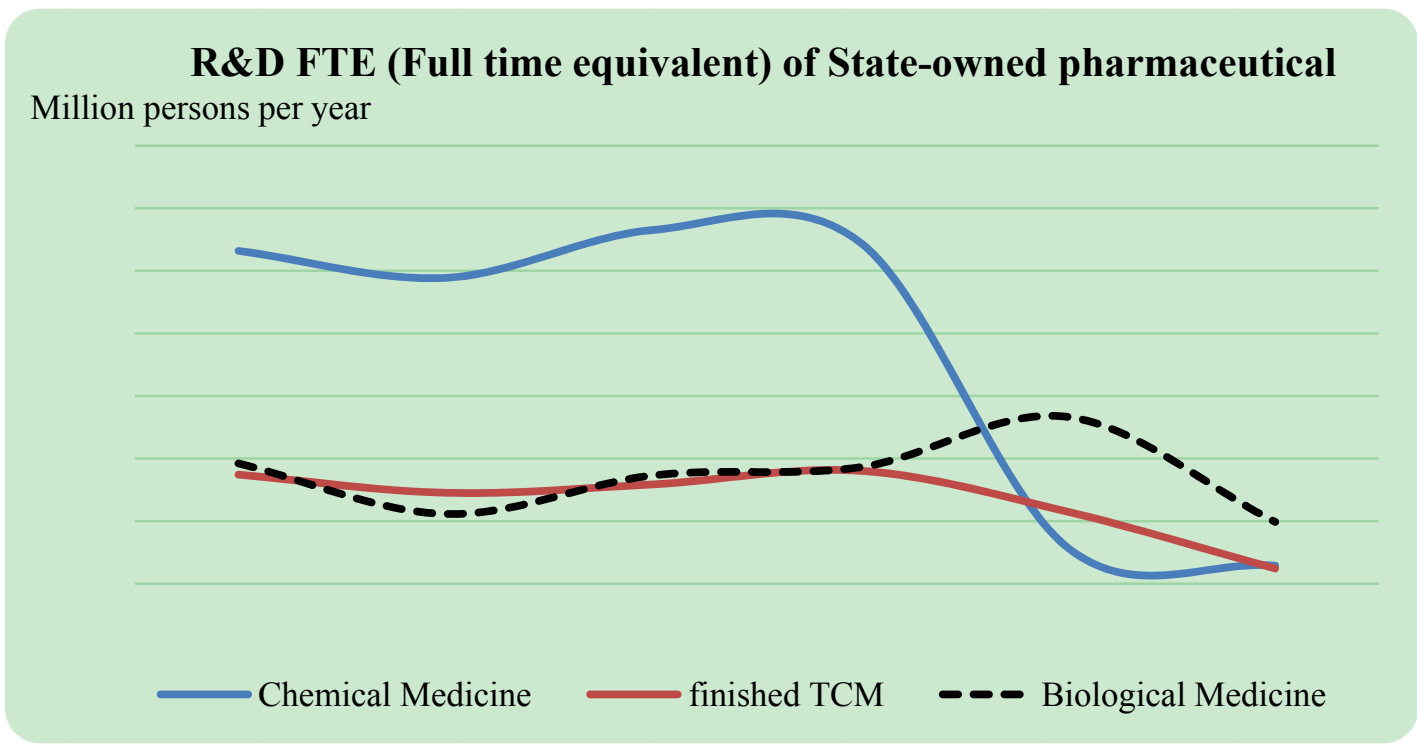

Figure 1. R\&D personnel situation of state-owned pharmaceutical enterprises

\section{Funds internal payments of State-owned pharmaceutical industry}

Ten thousand

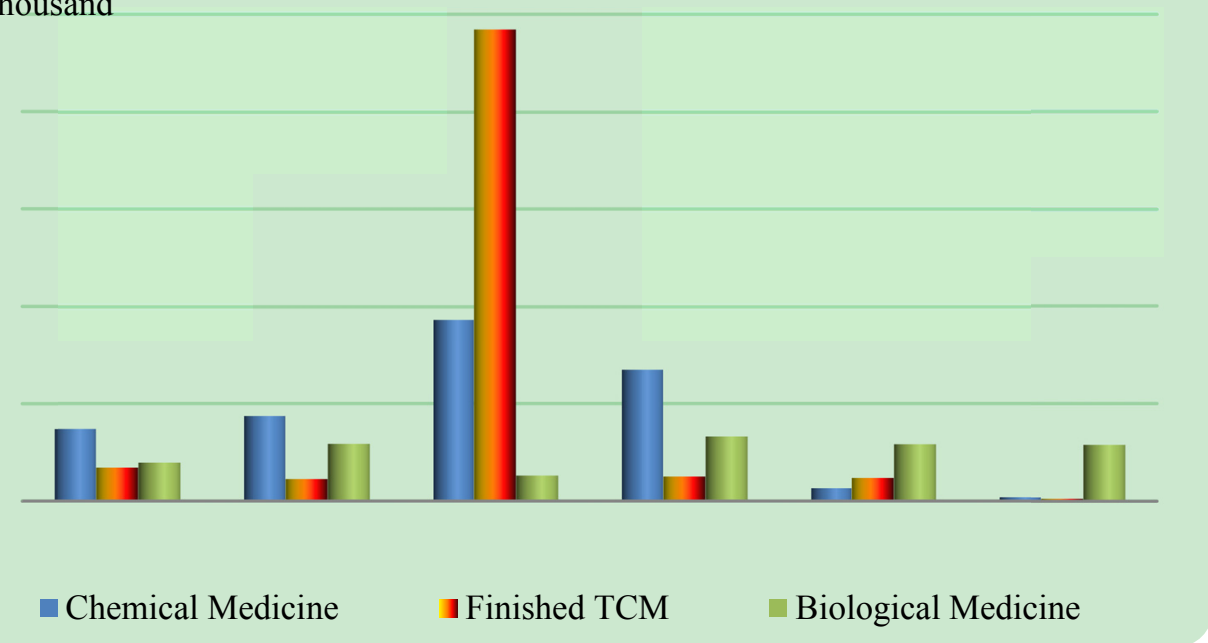

Figure 2. Research funding payments of State-owned pharmaceutical industry

Source: China Statistical Yearbook on High Technology Industry (2015).

\section{Analysis on the Innovation Behavior and Performance of State Owned Pharmaceutical Enterprises}

\subsection{The Dilemma of Risk Consciousness and Innovation in State Owned Pharmaceutical Enterprises}

The state-owned pharmaceutical enterprises bear the political task and social responsibility. At the same time, it also has the advantages of innovative development and structural adjustment. Private enterprises do not have these conditions to enjoy the benefits from the policy to the funding and then to the project and the state of the approximation of treatment, but they have better flexibility and adaptability. State owned and private, and the foreign capital integration, already achieve the advantages of complementary, the mixed ownership has become the most important institutional arrangements for the current choice of state-owned enterprises.

Due to a number of state-owned pharmaceutical enterprises for economic benefits, the national drug reserve, the employment rate of social development goals, the current state-owned property management system and determines the leadership of state-owned enterprises pay more attention to the risk decision, rather than the market profit performance, making the market risk consciousness of state-owned pharmaceutical enterprises than 
in private and foreign-funded enterprises; In addition, the state-owned enterprise leaders of CPC committees of selection, conditional tenure system and other systems, as well as national leadership assessment mechanism for the state-owned enterprises lack of innovative fault-tolerant mechanism, restricting the innovative ability of state-owned enterprises, the state-owned pharmaceutical enterprises exist the risk consciousness and a new dilemma. Therefore, play their respective advantages of state-owned enterprises, private enterprises, foreign capital market activity and the allocation of resources for the pharmaceutical industry, mixed ownership reform, state-owned pharmaceutical enterprises play an important role in the national economy and social security.

\subsection{Analysis on Malmquist Index of Innovation Performance of State Owned Pharmaceutical Enterprises}

The performance and evaluation of technical innovation, the European and American countries have accumulated rich experience. Innovation driven indicators of the Innovation Union Scoreboard 2014 (IUS) include human resources and financial support. R\&D investment indicators of the Science and Engineering Indicators include: R\&D investment, the number of scientific research personnel, and so on. The output index is the number of patents. Innovation performance evaluation of state owned pharmaceutical enterprises, input indicators is $R \& D$ personnel and $R \& D$ funds, output indicators for patent applications and new product sales revenue, based on DEA Malmquist index, estimate the dynamic change of 2010-2014 TEC in pharmaceutical enterprises' innovation activities, TEC $>1$ indicate efficiency improvement, means that correct direction on development mode and decision making of pharmaceutical enterprises, $\mathrm{TEC}<1$ indicate inefficiency, means that incorrect direction on development mode and decision making of pharmaceutical enterprises. DMU choose 11 high-tech industries in "Statistical yearbook of China's high tech industry", including three sub sectors of pharmaceutical manufacturing, such as the chemical, proprietary Chinese medicines and the biological products manufacturing.

Dynamic performance evaluation based on DEA Malmquist index shows that: overall technical efficiency from the perspective of innovation activities, biological products manufacturing $>$ Chinese traditional medicine $>$ Chemical manufacturing; In terms of ownership structure, State-owned enterprises $>$ Domestic funding enterprises $>$ Foreign enterprises $>$ Hong Kong, Macao and Taiwan enterprises; From inside the state-owned medicine enterprise interior point of view, the comprehensive technology innovation performance of pharmaceutical manufacturing industry in 2014 is better than other high-tech industries (Table 1). Therefore, state-owned enterprises take the industry leading and exemplary role in the realization of the pharmaceutical industry structure adjustment and transformation and upgrading of policy objectives, actively promote the reform of state-owned enterprises of mixed ownership, the effective integration of state-owned enterprises, private enterprises, foreign-funded enterprises and their innovative forms of ownership development advantage. 
Table 1. TEC of analyzing on pharmaceutical manufacturing (sub sector) industry

\begin{tabular}{|c|c|c|c|c|c|c|c|}
\hline & DMU & 2010 & 2011 & 2012 & 2013 & 2014 & Mean \\
\hline \multirow{11}{*}{$\begin{array}{l}\text { D } \\
0 \\
11 \\
0 \\
0 \\
1 \\
1 \\
0 \\
0 \\
0 \\
0 \\
0\end{array}$} & Chemicals manufacturing & 0.817 & 0.779 & 1.336 & 1.337 & 0.496 & 0.95 \\
\hline & Finished TCM manufacturing & 0.774 & 0.626 & 4.01 & 0.616 & 3.620 & 1.93 \\
\hline & Bio-medicine manufacturing & 0.663 & 0.453 & 2.15 & 1.159 & 2.217 & 1.33 \\
\hline & Communication equipment manufacturing & 1.280 & 1.406 & 1.175 & 0.801 & 1.018 & 1.14 \\
\hline & Electronic device manufacturing & 0.531 & 1.509 & 2.247 & 1.233 & 0.399 & 1.18 \\
\hline & Electronic components manufacturing & 4.348 & 0.272 & 1.215 & 1.685 & 0.598 & 1.62 \\
\hline & Home audio-visual equipment manufacturing & 0.846 & 2.478 & 0.427 & 2.645 & 1.187 & 1.52 \\
\hline & Other electronic equipment manufacturing & 0.729 & 2.641 & 0.599 & 5.171 & 0.703 & 1.97 \\
\hline & $\begin{array}{l}\text { Electronic computer peripheral equipment } \\
\text { manufacturing }\end{array}$ & 0.578 & 0.896 & 1.945 & 9.449 & 1.000 & 2.77 \\
\hline & Medical equipment and equipment manufacturing & 0.792 & 1.373 & 1.034 & 0.988 & 1.486 & 1.13 \\
\hline & Instrument and meter manufacturing & 0.776 & 1.890 & 0.527 & 1.684 & 1.514 & 1.28 \\
\hline \multirow{3}{*}{ 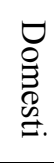 } & Chemical manufacturing & 0.939 & 0.973 & 1.206 & 0.896 & 0.934 & 0.99 \\
\hline & Finished TCM manufacturing & 1.089 & 0.813 & 0.948 & 0.959 & 1.052 & 0.97 \\
\hline & Bio-medicine manufacturing & 0.610 & 1.453 & 1.309 & 0.962 & 2.357 & 1.34 \\
\hline \multirow{3}{*}{ 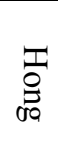 } & Chemical manufacturing & 0.841 & 0.877 & 1.548 & 0.955 & 0.781 & 1.00 \\
\hline & Finished TCM manufacturing & 1.231 & 1.086 & 0.768 & 0.946 & 0.736 & 0.95 \\
\hline & Bio-medicine manufacturing & 1.352 & 1.144 & 0.606 & 2.225 & 0.853 & 1.24 \\
\hline \multirow{3}{*}{ 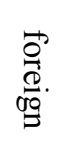 } & Chemical manufacturing & 1.207 & 0.911 & 0.984 & 0.879 & 1.183 & 1.03 \\
\hline & Finished TCM manufacturing & 0.944 & 0.931 & 0.899 & 0.674 & 1.072 & 0.90 \\
\hline & Bio-medicine manufacturing & 1.085 & 1.362 & 0.776 & 0.655 & 1.717 & 1.12 \\
\hline
\end{tabular}

Remarks: 2010-2014 high technology industry statistics calculated by the form of domestic capital, Hong Kong, Macao and Taiwan, foreign investment in the pharmaceutical industry in the manufacture of chemical, finished TCM and biological products.

\section{An Empirical Analysis of the Innovation Performance of State Owned Medicine Based on the Ownership Structure}

\subsection{An Overview of the Pharmaceutical Innovation Behavior of Ownership Structure}

Mixed ownership reform is a state-owned enterprise reform mode with Chinese characteristics, which has the advantage of the flexible management mechanism of private enterprises and the rich factor endowments of state-owned enterprises. KS Ji (2000) explore the mixed ownership of state-owned enterprises to bring vitality and vitality from the perspective of the continuous promotion of mixed ownership. S Pan (1999) explores the advantages and disadvantages of state-owned enterprises, mixed ownership enterprises, joint ventures and private companies and foreign respectively, pointed out that mixed ownership enterprises have a huge advantage from.

Technological innovation in the pharmaceutical industry, experts explore the impact of the ownership structure of the surface of the pharmaceutical innovation performance from domestic innovation platform construction, government support, and other foreign companies. SX Li (2015) consider that the pharmaceutical industry should pay attention to the construction of innovative research and development platform, improve the ability of collaborative innovation. YB Zhou (2015) consider that government support can reduce the risk of innovation of pharmaceutical enterprises and uncertainty, so as to stimulate the pharmaceutical enterprise innovation will change its innovation behavior; with the increasing of government efforts to support innovation, more conducive to the pharmaceutical industry to achieve transformation and upgrading. X Wu (2014) consider that the new drug $\mathrm{R} \& \mathrm{D}$ network, which is the goal and direction of the development of the pharmaceutical industry, is to build a 
new drug discovery and development network, which is formed by the mutual contact and interaction between enterprises, institutions and scientific research institutes. SQ Wu (2014) think that multinational pharmaceutical companies continue to enter the market China, new drugs and production technology with large foreign pharmaceutical companies and the impact should not be overlooked due to China local pharmaceutical enterprises from the perspective of domestic enterprises. Based on the above research results, the ownership structure has a very important role in stimulating the innovative behavior of medicine.

\subsection{Hypothesis and Index Selection}

Although the state-owned pharmaceutical enterprises have the advantage of resources, but there is a dilemma of risk awareness and innovation. How to play the role of state-owned pharmaceutical enterprises in the market guidance and demonstration of innovative development is one of the conditions to achieve the strategic objectives of national innovation and development strategy. Under the condition of ownership reform, the innovation behavior of pharmaceutical industry is different from resource acquisition, mainly in the aspects of human resource, capital, patent, export and so on. Therefore, the pharmaceutical industry profits to adjust the results of ownership innovation activities and direction, explore the influence degree of the development of pharmaceutical industry innovation of medical resources of economic benefits, so as to make full use of the ownership structure reform way to realize the development strategy of China's pharmaceutical industry innovation policy.

The PROFIT as the dependent variable to build Panel Data model, and using Employee, Rdfee, Patent, Scient, Export, Tech as the independent variable, the research object of the section is to determine the 4 forms of ownership (domestic capital, state-owned, Hong Kong, Macao and Taiwan funded, foreign capital enterprise), and using Panel Data from 2006 to 2014, build basic regression equation to analysis ration: $C$ is constant term, $a$ is coefficient, $t$ is time series, $i$ is forms of ownership.

$$
\begin{aligned}
& \text { PROFIT }_{i t}=a_{0} C_{i t}+a_{1} \text { Employe }_{i t}+a_{2} \text { RDfee }_{i t}+a_{3} \text { Patent }_{i t}+a_{4} \text { Scient }_{i t}+a_{5} \text { Export }_{i t} \\
& +a_{6} \text { Tech }_{i t} \quad i=1,2, \ldots, 4 \quad t=2006, \ldots, 2014
\end{aligned}
$$

\subsection{Model Construction and Analyzing}

The time dimension of the selected sample is 9 years, and the cross section is 4 forms of ownership. The empirical analysis of Data Panel is carried out by software EViews 7.0. In order to further analyze the correlation and influence degree of the pharmaceutical industry innovation resources to the profit of the pharmaceutical industry, the variable coefficient model $\left(\mathrm{F}_{2}=39.56>\mathrm{F}_{2 \alpha}(21,8) ; \mathrm{F}_{1}=22.40>\mathrm{F}_{1 \alpha}(18,8)\right)$. Regression results show that: the fitting degree of regression equation is good. After adjustment $R^{2}$ is $0.9974, D W$ is 7.76 (Table 2).

Empirical analysis data shows that: taking the profit as the dependent variable, the number of employees, the state-owned enterprises was significantly negatively correlated, and the domestic enterprises were not significantly related. R\&D expenses, the state-owned enterprises was significantly negatively correlated, domestic enterprises was significantly positively related; patent applications, the state-owned enterprises was significantly positively correlated, domestic enterprises were negatively related. Scientists and engineers, the state-owned enterprises was significantly positively correlated. In terms of export delivery value and technical transformation costs, state-owned enterprises are positively related, while domestic enterprises are negatively related; there is no correlation between Hong Kong, Macao, Taiwan and foreign enterprises (Table 2). 
Table 2. Regression results of the factors related to the profit of pharmaceutical manufacturing industry

\begin{tabular}{|c|c|c|c|c|}
\hline Variables & \multicolumn{4}{|c|}{ Regression coefficientsStandard deviationt- statisticT-Probability } \\
\hline Funded enterprises--C & -270.2712 & 278.0875 & -0.971893 & 0.3503 \\
\hline State-owned enterprises--C & 1303.497 & 207.2341 & 6.289973 & 0.0000 \\
\hline HK, Macao and Taiwan--C & 26.46812 & 78.36450 & 0.337757 & 0.7414 \\
\hline Foreign enterprise $-\mathrm{C}$ & -23.87395 & 49.37963 & -0.483478 & 0.6375 \\
\hline Funded enterprises-Number of employees & 0.000589 & 0.000477 & 1.235486 & 0.2403 \\
\hline State-owned--Number of employees & -0.000532 & 0.000136 & -3.905456 & 0.0021 \\
\hline HK, Macao and Taiwan -- Number of employees & -0.000711 & 0.001703 & -0.417475 & 0.6837 \\
\hline Foreign enterprise--Number of employees & 0.000257 & 0.000784 & 0.327215 & 0.7491 \\
\hline Funded enterprises - R\&D expenses & 0.001677 & 0.000222 & 7.567496 & 0.0000 \\
\hline State-owned --R\&D expenses & -0.004592 & 0.000674 & -6.818295 & 0.0000 \\
\hline HK, Macao and Taiwan--R\&D expenses & 0.000213 & 0.000752 & 0.283480 & 0.7816 \\
\hline Foreign enterprise--R\&D expenses & $-5.76 \mathrm{E}-05$ & 0.000465 & -0.123783 & 0.9035 \\
\hline Funded enterprises - patent applications & -0.100280 & 0.025139 & -3.989103 & 0.0018 \\
\hline State-owned--patent applications & 0.485725 & 0.063294 & 7.674063 & 0.0000 \\
\hline HK, Macao and Taiwan--patent applications & -0.005427 & 0.160358 & -0.033843 & 0.9736 \\
\hline Foreign enterprise--patent applications & 0.007827 & 0.049349 & 0.158609 & 0.8766 \\
\hline Funded enterprises-Scientists $\&$ engineers & 0.357203 & 0.548051 & 0.651769 & 0.5268 \\
\hline State-owned - Scientists \& engineers & -7.029519 & 1.270081 & -5.534701 & 0.0001 \\
\hline HK, Macao and Taiwan - Scientists \& engineers & -0.407277 & 1.535799 & -0.265189 & 0.7954 \\
\hline Foreign enterprise-Scientists \& engineers & -0.022180 & 2.220047 & -0.009991 & 0.9922 \\
\hline Funded enterprises-Export delivery value & -0.354481 & 0.202730 & -1.748535 & 0.1059 \\
\hline State-owned -- Export delivery value & 5.703626 & 1.572964 & 3.626038 & 0.0035 \\
\hline HK, Macao and Taiwan -- Export delivery value & 1.292728 & 1.072786 & 1.205019 & 0.2514 \\
\hline Foreign enterprise--Export delivery value & 0.816316 & 0.688528 & 1.185595 & 0.2587 \\
\hline Funded enterprises -- Technological funding & -0.001222 & 0.000192 & -6.377482 & 0.0000 \\
\hline State-owned -- Technological funding & 0.001457 & 0.000299 & 4.875082 & 0.0004 \\
\hline HK, Macao and Taiwan-- Technological funding & 0.000445 & 0.000732 & 0.607546 & 0.5548 \\
\hline Foreign enterprise -- Technological funding & 0.000113 & 0.000707 & 0.159733 & 0.8757 \\
\hline $\mathrm{R}^{2}=0.999186$ & & & stment $\mathrm{R}^{2}$ & 997355 \\
\hline $\mathrm{P}(\mathrm{F}-$ Statistic $)=0.00$ & 00000 & & $V$ Statistic $=2$ & 63200 \\
\hline
\end{tabular}

Data sources: China Statistical Yearbook on High Technology Industry (2015)

\subsection{Results and Conclusion}

The empirical analysis of the Panel Data model of pharmaceutical enterprises' profit and the related factors of industry innovation activity shows that there are some correlation between ownership structure type enterprises and innovation activities. Therefore, through the government's macro regulation and control in the process of reform of state-owned enterprises in the process of innovation, so as to achieve the national innovation system construction and the industrial upgrading.

1. Cost, total profit of state-owned enterprises and the development of the scientific research personnel quantity, science and the number of engineers was negatively related to state-owned enterprises R\&D resources are too concentrated and the phenomenon of excess, namely the development of resources and the current investment in state-owned enterprises can not reflect the current economic growth effect. Because of this, the current state-owned enterprises is still extensive development mode, need to adjust the stock, through mergers and 
acquisitions, mixed ownership reform and to promote the state-owned pharmaceutical enterprises R\&D performance evaluation mode, the transformation of the state-owned enterprises is the current performance.

2. There was a significant positive correlation for the total profits of state-owned pharmaceutical enterprises and patent quantity, export delivery value, technical renovation costs, showing the state-owned enterprises are the main force to realize medical innovation activities based on economic growth, but also will become the foundation of the national innovation ability construction, national innovation system of state-owned pharmaceutical enterprises.

3. Domestic corporate profits and the cost of technological innovation, patent applications were negatively correlated, domestic corporate profits and R\&D expenses were positively correlated, showing the Funded enterprises attached great importance to R\&D input and output performance, and access to corporate profit growth.

\section{Innovation Ability of State Owned Enterprises under the Background of the Reform of Ownership Structure}

\subsection{Market Integration and Radiation of State Owned Enterprises}

The ownership forms of state-owned pharmaceutical enterprises, originated in the planned economy since 1950s. For example, in August 1950 it set up a unified management of the pharmaceutical circulation of the main channel of the Chinese pharmaceutical company; in 1964, the pharmaceutical industry trust, founded Chinese pharmaceutical company to implement centralized and unified leadership and professional management of the pharmaceutical industry, the China National Pharmaceutical Group established in 1998. The development process of state-owned pharmaceutical enterprises, which fully shows the greater market integration and regional radiation, but at that time is still extensive mode of production based, enterprise innovation ability is weak.

At present, the Chinese Medicine Group is in charge of the national drug reserve task, the main channel of special drug distribution tasks, the national basic drug distribution base, with economic benefits, social responsibility and political responsibility, in order to improve the innovation ability, the Chinese Medicine Group should also shoulder the political responsibility. In the national innovation strategy, generic technology diffusion state-owned pharmaceutical enterprises brought about by the patent application and general technology, export and technology aspects of structural adjustment, with other ownership structure of pharmaceutical enterprises do not have the advantage, it is necessary to play a role in the integration of radiation and enterprise innovation development. In September 2015 "on deepening the reform of state-owned enterprises in adhering to the party's leadership to strengthen party building in a number of opinions", fully reflects the market integration and radiation effect of the pharmaceutical enterprises in the drug supply and innovation development.

\subsection{Micro Level Cooperation in the Context of Collaborative Innovation}

Mixed ownership reform has great significance for China's pharmaceutical industry earlier to achieve full market of great significance. Because of the fully competitive state-owned enterprises, foreign invested enterprises, private enterprises in the market, in order to show the different types of ownership enterprises advantage; therefore, the ownership of the enterprise market competition and cooperation, it is mixed ownership of property based on the structure of ownership advantage. The negative correlation between profit and human resources and funds of state-owned pharmaceutical enterprises shows the redundancy of R\&D intensity, so it is the fact that the micro level cooperation of state-owned enterprises in the context of collaborative innovation.

At present, the domestic pharmaceutical industry research institute, CAS (Chinese Academy of Sciences) system, and bear the support system of national technological innovation of large and medium-sized state-owned enterprises social responsibility and an important political task, such as related to the drug development and beneficial to the people's livelihood reserves by PPP (R\&D outsourcing cooperation of state and Society) mode is a good choice. The mixed ownership arrangement for the pharmaceutical industry organization system, Sinopharm Group and private enterprises Fosun Pharmaceutical joint venture in bio-pharmaceutical industry proves that mixed ownership in the high degree of market, rapid development is successful. The basis of this property right is to put all kinds of forms of ownership enterprises on a market equality and cooperation platform, and then in accordance with the ownership of the distribution of interests and rights, the realization of the micro level of separation of powers and checks and balances.

\subsection{Organizational Structure Adjustment of Innovation Industry Chain}

The pharmaceutical industry chain in $20^{\text {th }}$ Century planned economy pattern in China, using the "one, two, three grade, and zero transfer" (i.e., grade one and grade two, grade three, wholesale and retail pharmacies), pharmaceutical innovation industrial base located in the CAS system and the Institute of pharmaceutical industry, 
pharmaceutical enterprises mainly in production management enterprise independent innovation ability is very weak. With the $20^{\text {th }}$ Century 90 years to make a fortune to engage in three timber, timber and medicinal herbs, the whole competitive market liberalization, enterprise independent innovation capability issues become an important way to enhance the competitiveness of pharmaceutical companies. In the adjustment of organization structure, GP Wang (2012) proposed R\&D activities of CRO (external R\&D outsourcing) shall be adjusted on drug research organization; $\mathrm{ZB} \mathrm{Wu} \mathrm{(2014)} \mathrm{put} \mathrm{forward} \mathrm{ways} \mathrm{to} \mathrm{realize} \mathrm{the} \mathrm{transformation} \mathrm{of} \mathrm{enterprise}$ organization model usually has three ways, namely, change of organization mode of organization centered change, organization mode at the core of technology personnel as the center of the organization pattern changing; therefore, the organizational structure adjustment of state-owned enterprises, the urgent need to adapt and compete in the market of domestic and foreign pharmaceutical research and development.

The results of the analysis of the form innovation behavior of the medical system show that there is no correlation between the profit of the Hong Kong, Macao and Taiwan and foreign enterprises and the R\&D resources endowment, that is, the domestic pharmaceutical innovation activities must rely on domestic funded enterprises and state-owned enterprises. The organizational structure adjustment innovation of pharmaceutical industry chain, can take on the downstream mergers and acquisitions or cooperation, mergers and acquisitions and CRO, small companies, and the upper reaches of the CAS system in Institutions of higher learning, the formation of collaborative innovation system, through mergers and acquisitions or cooperation with professional sales company further downstream, organization structure to strengthen the state-owned pharmaceutical innovation industry chain.

\subsection{Cross Regional Integration of Pharmaceutical Innovation Resource Endowment}

The differences of knowledge innovation resources, information resources, industrial innovation environment, innovation of medical personnel endowments and other areas in our country, forms pharmaceutical manufacturing technology difference of regional innovation resources, provide the conditions and opportunities for cross regional innovation resources integration. In the implementation of cross regional integration strategy of pharmaceutical innovation resource endowment, the state-owned pharmaceutical enterprises bear the important role. Based on the economic benefit, social responsibility and political task of stated-owned enterprises, Sinopharm Group and Huarun Group within the countrywide scope about the advantage of innovation resources allocation, participate in the ownership structure of the pharmaceutical enterprises of mixed ownership reform.

The specific way of mixed ownership reform can take stock transfer mode, that is to maintain the original size of the state-owned enterprises unchanged, the division of enterprise capital ratio, transfer to the regional capital; it can also take the incremental investment way, increase the investment in the basis of the original scale of state-owned enterprises, the introduction of regional innovation resources, so as to change the structure of property rights of state-owned enterprises. For example, the demonstration effect of the export and structure adjustment about the state-owned pharmaceutical enterprises, is an important force in the cross regional integration of China's pharmaceutical innovation resource endowment.

\section{Conclusion}

Mixed ownership is a state-owned enterprise reform mode with Chinese characteristics, which has the integration advantages between the flexible operation mechanism of private enterprise and the rich endowment factors of state-owned enterprises. Mixed ownership reform is successful in the high degree of marketization, the rapid development of the bio-pharmaceutical industry. State-owned enterprises, such as the leadership selection, tenure system, innovation and fault tolerance mechanism, often make the state-owned pharmaceutical enterprises have a dilemma of risk awareness and innovation. Based on the advantage of resources elements, the pharmaceutical enterprises still achieved good innovation performance in biological products manufacturing field, and the advantages of the export and the structure adjusting, give full performance of the state-owned capital in the leading and exemplary role in the implementation of national pharmaceutical industry innovation development strategy.

\section{References}

European Commission. Innovation Union Scoreboard. (2014). Brussels.

Gao, T. M. (2009). Econometric analysis methods and modeling. Beijing: Tsinghua University press.

Ji, K. S. (2000). Reflections on promoting the development of mixed ownership economy. Exploration of Economic Problems, (2), 12-14.

Li, S. X. (2015). Pharmaceutical industry in China based on structure behavior performance paradigm. Chinese 
Pharmacy, 26(19), 2597-2600.

Luo, Q. (2014a). Introduction to the science and engineering indicators of the United States in 2014 -knowledge technology intensive industry and R\&D investment. Global Scientific And Technological Economic Outlook, (4), 11-15,20.

Luo, Q. (2014b). An introduction to the science and engineering indicators of the United States in 2014 -science and technology human resources and scientific research output. Global Scientific And Technological Economic Outlook, (5), 14-18.

Pan, S. (1999). On "mixed economy" in China. Contemporary Economic Research, (9), 18-23.

Wang, G. P., Ding, D., \& Zhang, X. P. (2012). Study on the structural adjustment of Chinese pharmaceutical industry during the period of "12th Five-Year". Chinese pharmacy, 26(10), 1060-1065.

Wu, H., Zheng, Y. G., Chen, Y., \& Ji, L. J. (2014). Exploration on the construction and basic characteristics of the network of new drug discovery and development in China from the perspective of major new drug discovery project "11th Five-Year". Chin J New Drugs, 23(21), 2465-2469.

Wu, S. Q., Xiao, X., Chen, Y. W., \& Tao, X. T. (2014). A comparative study on the innovation capability of pharmaceutical enterprises in the developed provinces of China. Economic Research Reference, (65), 86-91.

Wu, Z. B. (2014). Construction principles and characteristics of the organization pattern of mixed ownership enterprises in the period of transition. Shopping Mall Modernization, (31), 146.

Zhou, Y. B., \& Feng, G. Z. (2015). Study on the influence of government financial support on the innovation behavior of pharmaceutical enterprises. Chinese Medicine Evaluation, 32(3), 181-185.

\section{Copyrights}

Copyright for this article is retained by the author(s), with first publication rights granted to the journal.

This is an open-access article distributed under the terms and conditions of the Creative Commons Attribution license (http://creativecommons.org/licenses/by/4.0/). 